\title{
Thoughts on the Management and Development of University-affiliated Enterprise
}

\author{
Luo Xu \\ Wuhan University of Technology, Wuhan 430070, China.
}

\begin{abstract}
This paper proposed a series of management ideas and approaches to deal with the problem of lacking effective supervision in university-affiliated enterprise according to years of work experience in universities operating assets management. The ideas and approaches have theoretical and practical value in the management of University-affiliated enterprise.
\end{abstract}

Keywords: University-affiliated enterprise; management; development.

\section{Introduction}

"Long-term Education Reform and Development Plan (2010-2020) in China" has specifically defined that universities need to strengthen the social service capabilities, promote research with the combination of accelerating scientific and technological achievements, as well as regulate owned industries. [1]

"The Ministry of Education Several Opinions on Further standardize and strengthen the relevant institutions of higher learning directly under the State-owned Assets Management" (Jiao Cai [2015] No.6), which published by Ministry of Education in June 2015, has emphasized that universities must remain committed to manage state capital and strengthen supervision of state-owned assets, so as to accelerate the separation speed of institutions and enterprises with clear responsibilities, and prevent loss of state assets, as well as increase the value of state assets. Moreover, the implementation of innovation-driven development strategy is benefit for the combination among enterprises, universities and institutes to enhance the transformation efficiency of high-tech achievements and the growth of science and technology enterprises. [2]

There is no doubt that university-affiliated enterprise is the bridge between scientific \& technological research and achievements industrialization, which has played a significant role in achievement activities and made outstanding contributions in rapid development of high-tech. However, with the rapid development of university-affiliated enterprise, especially the extend of industrial chain business, the corruption is frequently caused. The main reason is inadequate supervision and lack of laws and regulations. So, how to supervise university-affiliated enterprise effectively, so as to prevent loss of assets and keep healthy development of university-affiliated enterprise has become an important issue in universities and educational administrative departments.

\section{Definition of University-affiliated Enterprise}

University-affiliated enterprises are established by universities with their own shares of technology or cash investments to improve efficiency of achievements industrialization and personnel training. Compare with general enterprise, the biggest difference is that university-affiliated enterprises not only manufacture products to create social value, but also shoulder mission of personnel training.

\section{Development of University-affiliated Enterprise}

The rise of university-affiliated enterprise started in 1950s and many early university-affiliated enterprises are established with the guideline of "Combining education with productive labor" at that time. Between 1970s and 1980s, university-affiliated enterprise experienced a vigorous historical period and universities used their own scientific and technological advantages, many large or small-run university-affiliated enterprises are established in that period, there are also some 
influential enterprises among them, such as Founder Group. From 1990s to now, university-affiliated enterprises have been rapidly developed with the proceeding of reform and opening-up in China. [3]

According to Chinese university-affiliated enterprises statistics, there are totally 5279 university-affiliated enterprises in 552 universities among 29 provinces and the total assets reached about 353.806 billion Yuan. The assets of Subordinate Universities of Ministry of Education are 316.707 billion Yuan (89.51\%). The top two university-affiliated enterprises of assets are Peking University and Tsinghua University, which respectively reached 117.656 billion Yuan and 97.12 billion Yuan. It is estimated that the total assets in Chinese university-affiliated enterprises nearing 450 billion Yuan. [4]

\section{Problems in University-affiliated Enterprise}

\subsection{Unclear Property Rights.}

In reality, university not only gave funds investment, but also invested permanent assets to support for the establishment and development of university-affiliated enterprise. However, corporate assets and state-owned assets are difficult to distinguish with time change, which leads to great difficulties in property rights between universities and enterprises. [5]

\subsection{Unclear Management System.}

Because of unclear property rights, the management system becomes uncertainty with many problems. It has been disputed that university-affiliated enterprise should operate by university or independent business. Some university administrators operate university-affiliated enterprise as a secondary unit and make frequently intervention on ordinary business of enterprise. In contrast, some university administrators pay no attention on the development of university-affiliated enterprise, which leads to ineffective supervision and lose of state assets.

\subsection{Inadequate Incentives.}

Some university-affiliated enterprises mainly take advantages of teachers' patent investment, but business management is different from teaching and scientific research. As a result, the university-affiliated enterprise administrators are not good at enterprise operation and the reward policy is also unattractive for talents to join in university-affiliated enterprise.

\section{Thoughts on the Management and Development}

(1) Improving management mechanism and establishing assets Management Company.

The university can establish asset Management Company to execute shareholder rights and regulate outside investment, so as to strengthen capital management and enhance management, monitoring and evaluation of university-affiliated enterprise. The asset Management Company not only represents university to be in charge of outside investment, but also the operating assets supervision and management. The "Three Board" (Shareholders Board, Directors Board and Supervisory Board) have constituted the company's organizational structure and hired senior lawyer as an independent director. The Supervisory Board is composed by department heads of supervision, finance, audit, as well as employee representative to supervise decision-making of companies' management.

(2) Improving management system and implementing effective supervision.

It is necessary to formulate and improve regulations of "State-owned Assets Management Policy", "Operating Assets Management Policy", "University-affiliated enterprise Supervision and Management Policy", "University-affiliated enterprise Target Responsibility Assessment and Management Policy", etc., to realize comprehensive management of university-affiliated enterprise.

The management of university-affiliated enterprise should follow the principle of "regulatory classification, democratic decision-making, control risk and tracing performance". For example, the 
activity of corporate restructuring, free transfer shares, corporate write-off, outside investment and candidates of directors, supervisors and managers should be determined by group decision-making.

The university should make a clear understanding of the risks for transfer assets between non-operating assets and business assets, as well as assessment and investment of patents and intangible assets. It is better to determine the person in charge for different position, develop preventive and supervisory measures and give regular risk inspection, so as to ensure no loss of state assets.

The university can delegate finance manager into asset Management Company for financial regulation, as well as discipline inspector for honesty strengthen. Also, the university can regularize behavior of leaders in company according to the relevant regulations of National Ministry of Education.

(3) Accelerating science and technology achievements transformation and supporting for the development of university-affiliated enterprise.

On one hand, university should use its rich technical and human resources to make scientific and technological cooperation with university-affiliated enterprise. There are many intangible assets, such as patent, proprietary technology, etc., that the university can invest to university-affiliated enterprise. It can also guide university-affiliated enterprise to apply for a variety of special funds and policy support, so as to promote the healthy and orderly development of enterprise with better technical and human resources support. On the other hand, university can established Science \& Technology Park by joint-stock system, so as to provide a platform for technology achievement industrialization with higher efficiency. Also, it can use BOT (Build-Operate-Transfer) mode to build technology incubator, so as to provide a platform for student innovation and entrepreneurship.

(4) Cultivating new exceptional talents and serving for social economic development.

The university should adjust the standards of personnel training according to enterprise needs and explore the innovation cooperative training model between university and enterprise. As a result, it can improve the knowledge structure and fit business needs. Also, optimizing the teaching content according to advanced technology in company and absorbing advanced business practices to enrich course content. Relying on university-affiliated enterprise can make contribution to writing new teaching material or improving teaching material. Also, the enterprise's outstanding personnel can join in education group as a part-time teaching staff.

Relying on industry advantages of university to enhance students' practical ability and build the Excellent Engineers Engineering Education Practice Model "University + Company + Brand". The university can establish Practice Education Center in university-affiliated enterprise to assist students learn the most advanced technology, equipment and enhance students' application capabilities of new technology and equipment in campus, so as to provide high quality human and technical resources for healthy development of society.

\section{Conclusion}

In summary, university-affiliated enterprise should improve their management mechanism and system to identify their own position, as well as rely on university's advantages of industry, intelligence and technology to realize health development and keep balance on economic efficiency and social benefits.

\section{References}

[1] Long-term Education Reform and Development Plan (2010-2020) in China. http://www.moe.edu.cn/publicfiles/business/htmlfiles/moe/moe_838/201008/93704.html.

[2] The Ministry of Education Several Opinions on Further standardize and strengthen the relevant institutions of higher learning directly under the State-owned Assets Management (JiaoCai [2015] No.6). http://www.moe.edu.cn/srcsite/A05/s7504/201507/t20150707_192795.html. 
[3] Wang Weixiong. Review of the Development for University Technology Enterprise [J]. Forum on Contemporary Education, 2006(1):53-54.

[4] Statistical summary of Campus Enterprises in China (2013). http://www.moe.edu.cn/publicfiles/business/htmlfiles/moe/s5972/201412/182627.html.

[5] Guo Xuehui. Thoughts on University Enterprise Development Direction [J]. Journal of Chongqing Institute of Technology, 2006, 20(1):150-152 